\title{
Strategists on the Board in a Digital Era
}

\author{
Carl Åberg ${ }^{1}$, Niloofar Kazemargi ${ }^{2} \&$ Max Bankewitz ${ }^{1}$ \\ ${ }^{1}$ Witten/Herdecke University, Germany \\ ${ }^{2}$ University of Rome, Tor Vergata, Italy \\ Correspondence: Carl Åberg, Witten/Herdecke University, Germany
}

Received: May 16, 2017

Accepted: June 3, 2017

Online Published: June 7, 2017

doi:10.5430/bmr.v6n2p40

URL: https://doi.org/10.5430/bmr.v6n2p40

\begin{abstract}
Considering the complexity and dynamics that firms are facing in a digital era, it is no exaggeration to argue that the way boards of directors contribute to strategy needs some new perspectives. In this article, we reconsider some of the commonly used notions and assumptions of board strategizing. We conceptualize a framework for board strategizing by revisiting and providing novel elements to the work introduced by McNulty and Pettigrew in 1999 (Strategists on the board. Organization Studies, 20(1): 47-74). Our framework highlights several timely board practices that have the potential to improve the way boards strategize under conditions of increasing digitalization. Further, the findings suggest that valuable strategic actions and priorities can be made by boards that use and develop dynamic capabilities as they strategize. Implications for theory and practice as well as future research directions are discussed.
\end{abstract}

Keywords: Boards of Directors, Digitalization, Dynamic Capabilities, Strategy

\section{Introduction}

"It used to be you made strategic decisions for five to seven years out. Now long-term planning is three years" - John Chambers, Cisco Chairperson (Spring, 2015).

This quote by the Chairperson of Cisco perfectly illustrates that strategizing is changing as we have entered a digital era. Such changes may be even more radical than illustrated above, which is foreshadowed by the fact that digitalization, referred to as "the integration of digital technologies into everyday life" (Croon Fors, 2013: p. 60), has shown to have tremendous impact, significantly changing societal and organizational behavior (McAfee \& Brynjolfsson, 2012; Newell \& Marabelli, 2015). More precisely, it has radically transformed how humans and businesses communicate, collaborate and make strategies (Constantiou \& Kallinikos, 2015; Newell \& Marabelli, 2015; Orlikowski \& Scott, 2014). In the light of these developments, researchers need to establish thorough understanding of how digitalization will impact management practices (Newell \& Marabelli, 2015; Tihanyi, Graffin, $\&$ George, 2014). To explore these developments, being regarded as very likely to happen, will allow organizational leaders to anticipate and cope with change that need consideration (Varum \& Melo, 2010). One specific strategic decision making group where it is particularly relevant to consider and discuss the shift of strategic conditions as of digitalization is the board of directors (Bankewitz, Åberg, \& Teuchert, 2016; Valentine, 2014; Yayla, 2014). It is particularly relevant since exploring new elements of board strategizing will help board members recognize, consider, and reflect on the uncertainties and changes they are likely to face in a society facing increasing digitalization.

Literature on board strategizing has lately produced an abundance of new knowledge (Bailey \& Peck, 2013; Garg \& Eisenhardt, 2016; Hendry, Kiel, \& Nicholson, 2010; Pugliese et al., 2009). This line of research has overall contributed to a better understanding of the behaviors and processes through which boards strategize. However, literature has to an insufficient extent precisely examined how board strategizing is taking new forms as of increasing digitalization in our societies (Tihanyi et al., 2014; Valentine, 2014). In line with these acknowledgments, we therefore argue that some of the long-standing assumptions of board strategizing should be reexamined while considering the impact of digitalization. This makes sense as researchers have argued that digital technologies applied to strategy processes have the potential to provide various opportunities for organizational decision makers (Tihanyi et al., 2014), as well as creating value for organizations (Brynjolfsson \& McElheran, 2016; McAfee \& Brynjolfsson, 2012). For these reasons, and since little is known about the altering perspectives in board strategizing caused by digitalization (Bankewitz et al., 2016; Tihanyi et al., 2014; Valentine, 2014), we argue that it is beyond time to give attention to this important topic. 
In this study, we revisit the work of McNulty \& Pettigrew (1999), who provide a framework that rigorously describes board involvement in strategy. Consequently, it fits the purpose of providing a good starting point to this research. McNulty and Pettigrew (1999) argue that board strategizing contains three main elements. First of all, board strategizing involves shaping strategic decisions and thus signaling the need for decisions and selling arguments. Second, boards are taking strategic decisions and thus make decision choices. Finally, boards are shaping the content, context and conduct of strategy, meaning that they set conditions under which strategizing happens (McNulty \& Pettigrew, 1999). We structure our research around these three elements of board strategizing while considering the consequences of digitalization. When examining the consequences of digitalization we give attention to boards in a general sense and follow the perception that all boards will be impacted by digitalization to some extent (Valentine, 2014). However, we acknowledge that the degree to which they are impacted by digitalization may differ depending on the context the firm is operating in.

We reconsider some existing views and assumptions on this topic and challenge current knowledge by applying the dynamic capabilities perspective (Eisenhardt \& Martin, 2000; Teece, 2007; Teece, Pisano, \& Shuen, 1997). This perspective provides a solid theoretical base for our framework as it addresses how boards can build strategic capabilities and processes, as a means of achieving long-term enterprise success. The development of such a framework makes three main contributions. First, we contribute to the board strategy literature by providing a framework describing board strategizing where digitalization plays a central role in changing board realities. As such, we contribute to the discussion that boards in the future might look and operate considerably different from what we know today (Bankewitz et al., 2016; Valentine, 2014). Secondly, we contribute to the dynamic capabilities perspective by pinpointing the importance of sensing, seizing, and reconfiguring, as well as ambidextrous behavior as boards engage in strategy. We show that the dynamic capabilities perspective can be purposefully applied to boards that face fast changing, complex, and uncertain environments as they strategize. Finally, our research provides a number of timely board practices that have the potential to improve the way boards shape strategic decisions, take strategic decisions, as well as how they shape the content, context, and conduct of strategy.

This manuscript proceeds as follows: First, we start with an introduction to the theoretical framework, emphasizing the application and importance of dynamic capabilities. Second, we present four major implications that digitalization will have on organizations. Third, we analyze and propose how digitalization will impact board of director's involvement in strategizing. The analysis concludes with theoretical and practical implications, and a consideration of limitations and future directions.

\section{Dynamic Capabilities}

The dynamic capabilities framework underscores the importance of firms' adaption to changing environments and the capabilities to achieve strategic change and long term advantages. As defined by Teece et al. (1997: p. 516) dynamic capabilities concern "the firm's ability to integrate, build and reconfigure internal and external competencies to address rapidly changing environments". This perspective is especially promising as an aid to understand the foundation of long-term enterprise success in increasingly demanding environments facing global challenges and fast-pace technology advancements (Augier \& Teece, 2008; Kor \& Mesko, 2013). By highlighting the importance of strategy as well as leadership, it can help a wide range of decision makers, including boards, outline relevant strategic actions and priorities they should adopt to enhance firm performance (Adner \& Helfat, 2003; Beck \& Wiersema, 2013). Decision makers fulfill their role by modifying short-term strategic positions in order to build long-term advantages for their firms (Eisenhardt \& Martin, 2000; Teece, 2007). More specifically this encompasses three central capabilities (sensing, seizing, and reconfiguring) that have come to be accepted in the dynamic capabilities literature after being introduced by Teece (2007). First, sensing concerns the capability where opportunities and threats are identified and shaped through scanning, anticipating and interpretative activity. Second, seizing is the capability that concerns making the right decisions and executing them. Finally, reconfiguring encompasses the capability of enhancing and altering organizational assets and structures as markets and technologies change. These collective capabilities are important factors that separately and in combination influence the strategic decisions that principal decision makers take (Helfat \& Peteraf, 2015; Teece, 2007). Furthermore, they are important strategic routines and have been commonly examined to understand corporate strategy and the strategic actions of the corporate elite. Consequently, it makes sense to apply this framework to boards of directors who have been argued to be increasingly involved in corporate strategy (Pugliese et al., 2009) and have been found to have a great impact on strategic outcomes (Golden \& Zajac, 2001; Haynes \& Hillman, 2010; Jensen \& Zajac, 2004).

A central premise of the dynamic capabilities perspective surrounds the ability of a business and its managers to be ambidextrous (O'Reilly \& Tushman, 2008). In this sense, ambidexterity is the simultaneous exploration and 
exploitation of both emerging and mature market opportunities and technologies (Taylor \& Helfat, 2009; Tushman \& O'Reilly, 1996). Exploration is about developing new technologies and opportunities by applying search, discovery, innovation, autonomy and embracing variation. Exploitation, on the other hand is about exploiting existing assets by focusing on efficiency, productivity, control and variance reduction (Gibson \& Birkinshaw, 2004). For the purpose of this article, ambidexterity provides a valuable extension of the dynamic capabilities perspective as it can help explain how technological transitions which firms are experiencing as of digitalization should be handled by boards. Especially in these situations, often characterized by technology and market uncertainty, ambidextrous behavior has been found to have positive implications on firm performance (O'Reilly \& Tushman, 2013). To successfully navigate technological transitions, firms can benefit from exploiting existing assets and exploring new core technologies simultaneously (Taylor \& Helfat, 2009). In these situations, boards may facilitate ambidexterity by embracing dynamism and change rather than stability and certainty. By embracing dynamism and change they often encourage learning, integrating and transferring knowledge as well as accepting failure (O'Reilly \& Tushman, 2008). Consequently, they place organizations in a better position to handle business transitions and strategic change.

\section{The Impact of Digitalization on Organizations}

Digitalization has already shown to have tremendous impact, significantly changing societal and organizational behaviors and structures (Newell \& Marabelli, 2015; Orlikowski \& Scott, 2014). The quote by Jeff Immelt, CEO and Chairmen of General Electric, clearly speaks for these arguments: "If you went to bed last night as an industrial company, you're going to wake up this morning as a software and analytics company." Consequently, such implications are having a tremendous impact on the way firms do business and has in some industries completely rewritten the rules of competition (Hirt \& Willmott, 2014). We expand on the work introduced by Bankewitz et al. (2016) and argue that there are a number of specific digital trends that will impact organizations and specifically boards involvement in strategizing. They include changing strategic contexts, data driven decision making, short term strategizing, and disappearance of organizational boundaries.

\subsection{Changing Strategic Contexts}

Digitalization has great impact on how firms do business and is causing rapid shifts in the strategic environment (Constantiou \& Kallinikos, 2015; McAfee \& Brynjolfsson, 2012). These rapid shifts bring new meaning to the competitive position of companies, where temporary advantages are developed opposed to sustained competitive advantages (Kriz, Voola, \& Yuksel, 2014). Furthermore, on-going dynamics in the competitive environment caused by digitalization is disrupting existing value-chains and business models, thus redistributing profits in these markets. Today some of the most profitable enterprises are applying strategies and business models which would not have been possible without the latest developments in digitalization (Altman \& Tushman, 2017; Orlikowski \& Scott, 2014). These business models have allowed for better ways to satisfy customer needs and have redistributed profits to firms who have challenged the very basics of their industry (Binns, Harreld, O'Reilly, \& Tushman, 2014). Uber and Airbnb are good examples of such firms. Part of their success is a digital business model relying on a "platform matchmaking strategy" that uses digital technologies as a key enabler (Altman \& Tushman, 2017). These changing strategic contexts and new business models impose major threats to existing players who need to find better ways to satisfy their customers.

\subsection{Data Driven Decision Making}

It has been widely acknowledged by researchers that better data creates opportunities to make better decisions (Constantiou \& Kallinikos, 2015; McAfee \& Brynjolfsson, 2012). Hereby, digitalization has vastly increased the scale, scope, and frequency by which data is updated and made available to organizations and its decision makers (Newell \& Marabelli, 2015). This type of data, often referred to as big data, induces great changes to the way decisions are going to be made in the future (Constantiou \& Kallinikos, 2015). Due to big data, decision makers have more information available about their business and can make more efficient predictions of trends, and analyze customer preferences more precisely. As such, they can create evidence-based realities of markets, industries and economies, thus facilitating efficient decisions (Drnevich \& Croson, 2013). In this regard, big data is linked to the organizational strategy, and the way organizations perceive, assess and act upon the opportunities and threats in their internal and external environments (Constantiou \& Kallinikos, 2015). Furthermore, if used in the strategic process, big data can be translated into knowledge that may in turn improve decision making and performance (McAfee \& Brynjolfsson, 2012).

These opportunities impose great changes on organizations, and their strategy and decision making culture. By using big data, senior decisions-makers are forced to embrace evidence based decision-making rather than forming their decisions based on intuition. Consequently, firms rely on data scientists who can detect patterns in data using 
algorithms, and visualize those to decision makers (Constantiou \& Kallinikos, 2015; Davenport \& Patil, 2012; Newell \& Marabelli, 2014). This redefines our understanding of decision making to a process where senior leaders are less likely to make human-centered judgments by using their experience and knowledge (McAfee \& Brynjolfsson, 2012).

\subsection{Short term Strategizing}

The constant updatability of big data means that information about consumers and competitive environments are produced continually (Constantiou \& Kallinikos, 2015). Using this data in the strategy process enables firms to quickly sense and seize opportunities through real-time responses (Bankewitz et al., 2016). With constant and frequent updatability of information strategic tools with the purpose of making long-term forecasts are challenged. Instead, firms adjust to short-term strategic planning where flexibility and adaptability to constantly changing environments become increasingly important. Such firms study consumers in real time to anticipate and influence their behavior, and form strategies based on that (van den Driest, Sthanunathan, \& Weed, 2016).

\subsection{Disappearance of Organizational Boundaries}

In the past, most organizations have routinely interacted with their suppliers, customers, and other external parties. Organizations adjusting to digitalization are increasingly external in their focus (Altman \& Tushman, 2017; Newell $\&$ Marabelli, 2014). They recognize the opportunities of sharing information and knowledge across boundaries with external players. Consequently, they apply "boundary spanning strategies" where external parties play an important role in the strategic success of the firm (Altman \& Tushman, 2017). For example, in R\&D, leaders look beyond internal functions and consider innovation sources beyond organizational boundaries, known as open innovation or collaborative innovation.

\section{Board Strategizing}

Board members have been described as expert strategists that possess valuable strategic problem-solving expertise that they can apply to strategic processes of choice, change, and control (Forbes \& Milliken, 1999; McNulty \& Pettigrew, 1999; Rindova, 1999). Consequently, it has been found that boards' involvement in strategy profoundly impacts the strategic direction of organizations (Golden \& Zajac, 2001; Haynes \& Hillman, 2010; Jensen \& Zajac, 2004; Westphal \& Fredrickson, 2001). Boards' involvement in strategy builds on two main theoretical perspectives. From an agency theory standpoint, boards have been argued to determine strategy choices by preventing firm management from behaving opportunistically (Fama \& Jensen, 1983). As such they ratify and monitor the content, context, and conduct of strategy. From a resource dependency theory and resource based view stance, boards support managers in the strategy process. Consequently, they support the initiation, formulation and implementation of strategy. Researchers have underscored that board of directors involvement in strategy is complex and differs from other decision making teams in the upper echelon (Finkelstein, Hambrick, \& Cannella, 2009). First of all, they often lack the necessary expertise and have inferior access to information which complicates their involvement in strategizing (Boivie, K. Bednar, Aguilera, \& Andrus, 2016; Stiles, 2001). Second, they meet on an irregular basis which can limit their ability to work as a team. Lastly, the dual nature of the two main tasks that boards perform, monitoring and providing advice, are contrasting approaches to corporate governance with opposing elements (Sundaramurthy \& Lewis, 2003). Consequently, it may be difficult to balance these two tasks, and how boards balance's them will impact their strategizing. Accordingly, boards encounter unique challenges that must be overcome in order to effectively strategize.

Considering these challenges as well as the changed realities as of digitalization, the way boards contribute to strategy needs new perspectives. In what follows, we build on the McNulty and Pettigrew (1999) framework to discuss and question how digitalization will impact board strategizing. The outcome is visualized in Table 1. 
Table 1. Board strategizing in a digital era

\begin{tabular}{|c|c|c|c|c|}
\hline & & $\begin{array}{l}\text { Shaping strategic } \\
\text { decisions }\end{array}$ & Taking strategic decisions & $\begin{array}{l}\text { Shaping the content, } \\
\text { context and conduct of } \\
\text { strategy }\end{array}$ \\
\hline Theory & $\begin{array}{l}\text { Dynamic capabilities } \\
\text { •Sensing, seizing and } \\
\text { reconfiguring (Teece, } \\
2007) \\
\text {-Ambidexterity (O'Reilly } \\
\text { \& Tushman, 2008) }\end{array}$ & $\begin{array}{l}\text { Boards use their sensing } \\
\text { capabilities while shaping } \\
\text { strategic decisions } \\
\text { Through sensing } \\
\text { capabilities board members } \\
\text { broaden and overcome } \\
\text { rather narrow search } \\
\text { horizons possessed by } \\
\text { executive managers. } \\
\text { Boards sense opportunities } \\
\text { and threats across markets } \\
\text { and technologies }\end{array}$ & $\begin{array}{l}\text { Boards use their seizing } \\
\text { capabilities while taking } \\
\text { strategic decisions } \\
\text { Seizing capabilities allow } \\
\text { boards to solve problems, } \\
\text { and respond to } \\
\text { opportunities and threats } \\
\text { by making timely } \\
\text { decisions. }\end{array}$ & $\begin{array}{l}\text { Boards are figureheads for } \\
\text { using and promoting } \\
\text { sensing, seizing and } \\
\text { reconfiguring capabilities } \\
\text { when shaping strategy. } \\
\text { Boards act ambidextrously } \\
\text { as they conduct strategy. } \\
\text { They justify and build } \\
\text { ambidextrous behavior in } \\
\text { organizations. }\end{array}$ \\
\hline Practice & $\begin{array}{ll}\text { The impact of } \\
\text { digitalization } \\
\text { C } & \text { Changing } \\
& \text { strategic contexts } \\
& \text { (Constantiou \& } \\
\text { Kallinikos, 2015) } & \text { Data driven } \\
\text { decision making } \\
\text { (McAfee \& } \\
\text { Brynjolfsson, } \\
\text { 2012; Newell \& } \\
\text { Marabelli, 2015) } \\
\text { Short term } \\
\text { strategizing } \\
\text { (Constantiou \& } \\
\text { Kallinikos, 2015; } \\
\text { van den Driest et } \\
\text { al., 2016) } \\
\text { Disappearance of } \\
\text { organizational } \\
\text { boundaries } \\
\text { (Altman \& } \\
\text { Tushman, 2017; } \\
\text { Newell \& } \\
\text { Marabelli, 2015) }\end{array}$ & $\begin{array}{l}\text { Boards are increasingly } \\
\text { involved in shaping } \\
\text { strategic decisions. They } \\
\text { scan, anticipate, interpret } \\
\text { and discuss threats and } \\
\text { opportunities with } \\
\text { executives. } \\
\text { Internal forums that } \\
\text { enhance the shaping of } \\
\text { strategic decisions: } \\
\text { Brainstorming } \\
\text { sessions between } \\
\text { board members } \\
\text { and executives } \\
\quad \text { Dyadic } \\
\text { relationships } \\
\text { between board } \\
\text { members and } \\
\quad \text { executives } \\
\text { Boards actively interact } \\
\text { with a wider ecosystem } \\
\text { when shaping strategic } \\
\text { decisions. } \\
\text { External forums that } \\
\text { enhance the shaping of } \\
\text { strategic decisions } \\
\text { Virtual networks. }\end{array}$ & $\begin{array}{l}\text { Boards embrace data } \\
\text { driven decisions. Instead of } \\
\text { relying on their intuition } \\
\text { and opinions board } \\
\text { members rely more on } \\
\text { data. } \\
\text { Boards ask the right } \\
\text { questions and are less } \\
\text { valued for their expert } \\
\text { answers. } \\
\text { Structures are developed to } \\
\text { access and use data in real } \\
\text { time for decisions. } \\
\text { Interplay between data } \\
\text { scientists, executives and } \\
\text { board members become } \\
\text { increasingly important as } \\
\text { boards embrace data driven } \\
\text { decisions. Visualization } \\
\text { tools become important. }\end{array}$ & $\begin{array}{l}\text { The content of strategy is } \\
\text { more frequently shaped by } \\
\text { boards and the external } \\
\text { environment. Content of } \\
\text { the strategy is monitored } \\
\text { by people external to the } \\
\text { organization. } \\
\text { Strategy is formed in a } \\
\text { context of real-time } \\
\text { responses. Short term } \\
\text { strategic planning tools } \\
\text { become increasingly } \\
\text { important. } \\
\text { Conduct of strategy } \\
\text { becomes more } \\
\text { unstructured, uncertain and } \\
\text { abstract as of digitalization. } \\
\text { Instead of seeking stability } \\
\text { and certainty boards } \\
\text { embrace dynamism and } \\
\text { change. Boards encourage } \\
\text { experimentation, failure, } \\
\text { feedback, learning and } \\
\text { constant adjustments. }\end{array}$ \\
\hline
\end{tabular}

Source: own elaboration

\subsection{Shaping Strategic Decisions in a Digital era}

Decisions are shaped over time in a process where multiple aspects impact the final outcome. More specifically, a whole range of behavior in the decision process shapes the actual decision. This behavior, referred to as shaping strategic decisions, takes place before the actual decision taking. It predominantly takes place outside the boardroom (McNulty \& Pettigrew, 1999). For example, executives may consult board members to test their ideas. As such they seek advice from board members who serves as sources of knowledge and expertise (Zattoni, Gnan, \& Huse, 2015). With these arguments, it is evident that boards of directors influence the preparations of decision proposals and thus the final decision.

Digitalization is causing constantly changing strategic contexts thus disrupting existing value chains, business models, and industry structures (Ko \& Fink, 2010). Confronted with these developments, firms need to stay constantly tuned to what is happening in external environments as recognizing early warning signs of business disruption will be key to survival (Downes \& Nunes, 2013). Consequently, the shaping of board strategic decisions becomes increasingly important as a process where new events and developments are interpreted and discussed (Binns et al., 2014). Such a process allows boards to sense opportunities and threats, and thus shape new initiatives proactively in order to respond to constantly changing business environments (Collin et al., 2015; Helfat \& Peteraf, 
2015; Teece, 2007). McNulty and Pettigrew (1999) argue that only some boards shape strategic decisions. We suggest a possible future scenario where boards become increasingly involved in shaping strategic decisions in order to sense opportunities and threats, and make timely responses to changing business contexts in a digital world. Without their constant involvement in shaping strategic decisions firms will be disrupted and unable to compete in fast changing digital environments (Binns et al., 2014). Thus, we picture a scenario where boards form new constellations with the executive management through which they use their sensing capabilities to actively scan, anticipate, interpret, and discuss opportunities and threats. Garg and Eisenhardt (2016) have recently provided empirical evidence that effective board members strategize by forming dyadic relationships with executives. Furthermore, they form brainstorming sessions where board members and executives discuss the strategy in-between board meetings. These are effective ways of shaping the strategy as board members can broaden and overcome rather narrow search horizons, vested in many executive managers who may be tied to follow established perspectives (Teece, 2007). By broadening these search horizons, board members enhance scanning and exploring activities, that contribute to sensing capabilities.

As described by McNulty and Pettigrew (1999) the process of shaping strategic decisions is mostly an internally focused process where the interaction between the board members and the executives becomes focal. With the disappearance of organizational boundaries caused by digitalization the process of shaping strategic decisions extends in its focus beyond organizational boundaries (Newell \& Marabelli, 2015). The board sees the benefits of interacting with a wider business ecosystem to sense new business opportunities and threats as important input for shaping strategic decisions. As described by Bankewitz et al. (2016), boards may indeed fulfill these sensing activities by forming virtual networks that extend beyond organizational boundaries. Through the interplay with these virtual networks, boards can identify new opportunities, understand how markets are developing, develop their creative thinking, and propose novel offerings from a stronger external perspective. By emphasizing external perspectives boards can provide significant value. Especially by engaging in boundary spanning activities and developing organizations that value external input, which is often overlooked by executives who are more focused on internal environments, boards may contribute to superior strategies (Altman \& Tushman, 2017). Furthermore, a more externally focused board can play an increasingly active role in providing introductions and network connections which is needed as strategic contexts change and firms apply strategies (e.g. platform, open/user innovation, and ecosystem strategies) where external parties become integral to the success of the company (Altman \& Tushman, 2017). Through these and other related activities, the board plays an important role in shaping new commercialization opportunities across markets, and technologies, thus providing sensing capability to the firm (Teece, 2007).

\subsection{Taking Strategic Decisions in a Digital era}

When taking decisions board members exert their influence at the concluding point of the decision process. As the ultimate decision making body of organizations in many contexts, boards of directors have a significant role in taking decisions (Finkelstein et al., 2009). Boards typically take decisions when board members approve, disapprove, or refer proposals brought to the board by the TMT or the CEO (McNulty \& Pettigrew, 1999). In this process, they use their knowledge and experience to assess the strategic desirability of proposals presented and decisions suggested by executives.

As previously argued digitalization will reshape the ways in which information is generated, aggregated, and made available to decisions makers. Consequently, this will reframe the role of individual decision makers who more frequently embrace data when taking decisions (Brynjolfsson \& McElheran, 2016). Data-driven decisions are considered to be of superior quality as they have been found to have an positive impact on firm performance (Brynjolfsson \& McElheran, 2016). Consequently, firms apply these methods in a drastically growing rate (Brynjolfsson \& McElheran, 2016; McAfee \& Brynjolfsson, 2012). Eventually, we argue that boards will also embrace data-driven decisions as a common practice. Accordingly, this will be a big transition for boards who have been used to take decisions by using the experience and knowledge that board members possess (Finkelstein et al., 2009; Haynes \& Hillman, 2010). Instead of relying on their intuition and asserting their opinions what the future holds, boards will form their decision more frequently based on what the data says. Taking these developments into account, Newell and Marabelli (2015) have argued that the process of taking strategic decisions is likely to be a less human-centered and knowledge-based activity. However, access and ability to transform data may be an increasingly important factor that boards should attend to (Tihanyi et al., 2014). John Chambers, the Chairperson of Cisco demonstrates the practical relevance of this issue: 
"My worry is we will make decisions without the right data ... Our key is, how do you capture this data the way it allows you to combine information in a way that makes business outcomes? That's the challenge we face. - Spring (2015).

Accordingly, as the data-driven decision revolution advances in this direction, we predict that the role of board members will shift. It will be less likely that you see board members being described as superior decision makers that use their knowledge and skill to take efficient decisions even without complete information or data (McNulty \& Pettigrew, 1999; Rindova, 1999). Instead, we will probably more frequently observe their opinions and intuition to be overruled by data evidence (McAfee \& Brynjolfsson, 2012). They will not be valued for their expert answers but rather for the questions that they ask. More frequently you will see them ask: "What does the data say?", or "Where does the data come from?" Having access to the right data that is visualized and communicated in an understandable way will enable boards to take decisions and seize opportunities and threats in real time. This requires data scientists that can visualize the essence of what the data says, executives that can communicate the content of the data and board members that can understand and question the data, followed by efficient decisions (McAfee \& Brynjolfsson, 2012). A quick and smooth process is essential as the constantly changing strategic contexts reduce the time spans within which data is useful and relevant for decision taking (Constantiou \& Kallinikos, 2015). This requires the board to possess seizing capabilities that allow them to make timely responses and form clear decisions (O'Reilly \& Tushman, 2008; Teece, 2007). In other words, and in line with the dynamic capabilities perspective they use the data to modify short-term strategic positions to build long-term advantages.

\subsection{Shaping the Content, Context, and Conduct of Strategy in a Digital era}

Boards' involvement in shaping the content, context and conduct, of strategy is on a rise (Hendry et al., 2010; Pugliese et al., 2009), meaning that boards do not only influence strategy by shaping and taking strategic decisions, but also by shaping their content, context, and conduct, thus influencing the processes by which strategy evolve (McNulty \& Pettigrew, 1999). Through such involvement, they shape the future direction of organizations (Pye, 2002). As such, many boards have an aspiration to spend more time on shaping the strategy (Hendry et al., 2010). These developments can partly be explained by new challenges and complexities in business environments as well as advancements in the fields of corporate governance and strategic management where researchers have argued that board involvement in strategy leads to organizational performance (Garg \& Eisenhardt, 2016; Hendry \& Kiel, 2004; Pugliese et al., 2009).

Boards influence the content of strategy by evaluating and monitoring the decisions and actions that executives take. In this process, they may ask executives to justify their strategic intentions (McNulty \& Pettigrew, 1999). As described by McNulty and Pettigrew (1999), the content of strategy is shaped by the board. They describe an evolution from executives controlling the strategy process, towards a more open process where the board is more influential. In a digital world, we draw a scenario where this influence is extending the borders of the organization, in other words, that a wide range of stakeholders can influence the content of the strategy. This predicted change occurs as digitalization causes availability, access and flow of information to increase between organizations and individuals (McAfee \& Brynjolfsson, 2012; Orlikowski \& Scott, 2014). As such, based on mutual interests and objectives, individuals and organizations access and share information and knowledge with few restrictions in a digital era (Newell \& Marabelli, 2014). The mutual interests and objectives of these people may therefore impact the content of the strategy in a firm. The example of TripAdvisor, as illustrated in the case study by Orlikowski and Scott (2014), exemplarily shows that digitalization allows sharing of information to intensify competition and change industry structures. It has forced boards and company owners to become increasingly attuned to voices of the external environment. Consequently they are changing their organizational practices, business development activities as well as the content of strategy accordingly (Orlikowski \& Scott, 2014). These increasing external engagements and influences may have significant impact on the monitoring of strategic content. On the one hand, it may cause the board to engage in more oversight and monitoring considering the risks of sharing information and external engagements (Altman \& Tushman, 2017). In contrast, it may reduce the monitoring of the board as companies subject to online influences are consequently being managed and monitored by people external to the organization (Bankewitz et al., 2016; Orlikowski \& Scott, 2014).

The context of strategy is shaped by boards as they influence the tools and methods used to formulate, debate and develop the strategy (McNulty \& Pettigrew, 1999). With constant updateability of information, boards recognize the benefit of seizing new opportunities by making quick real time responses in order to adjust to current market trends and habits of customers. Traditional tools with the purpose of developing long-term predictions are challenged as it becomes increasingly difficult to predict future trends in volatile environments where strategic contexts are 
constantly changing (Constantiou \& Kallinikos, 2015; Davis, Eisenhardt, \& Bringham, 2009; Dreischmeier, Close, \& Trichet, 2015). As a result, we foresee a scenario where boards encourage their firms to apply short-term strategic planning where real-time responses become increasingly central in building long-term advantages (Bankewitz et al., 2016; Constantiou \& Kallinikos, 2015). To effectuate real time responses requires organizations to possess dynamic capabilities in order to explore opportunities ahead of competition (Zahra, Sapienza, \& Davidsson, 2006). In building these dynamic capabilities the board plays an important role in orchestrating team dynamics in the upper echelon of organizations and thus influencing the dynamic capabilities of their organization (Kor \& Mesko, 2013). This includes both sensing, seizing and reconfiguring capabilities.

Conduct of strategy is mainly seen as the behavior through which executives implement the strategy. Boards influence these behaviors by encouraging specific behaviors, establishes frameworks which promote specific behaviors or by monitoring behavior (McNulty \& Pettigrew, 1999). With constantly changing strategic contexts caused by digitalization, decision makers are faced with greater complexities and uncertainties as well as increasing pace of change at which strategies are needed to be formed (Kriz et al., 2014). In order to adjust to these constantly changing environments, boards need to promote the capabilities to sense and seize opportunities and threats, as well as reconfiguring firm assets as these capabilities are especially valuable in these environments (Teece, 2007). Furthermore, in volatile environments, the application of rational behaviors in strategizing do not fully hold as digitalization and the complexities it causes implies more unstructured, uncertain, and abstract conduct of strategy (Constantiou \& Kallinikos, 2015). As such, it will be challenging for executives to act consistently and stick to their commitments as they conduct strategy. To successfully navigate through these challenges, boards will increasingly need to encourage executives to ambidextrously manage different and inconsistent organizational alignments simultaneously (O'Reilly \& Tushman, 2008; Taylor \& Helfat, 2009). Instead of seeking stability and certainty they embrace dynamism and change. Successful executives faced with these challenges conduct strategy and take decisions consistently inconsistently (Smith, Lewis, \& Tushman, 2016). It means that they purposefully and confidently embrace the paradoxes that they confront. For example, boards may need to embrace the paradox of exploiting existing assets at the same time as they explore new technologies and markets. To explore and exploit at the same time requires that the board formulates a vision and strategy that justifies the ambidextrous behavior and intent (O'Reilly \& Tushman, 2008). Consequently, boards need to encourage behavior that emphasizes the value of experimentation and failure while promoting feedback to enable learning and constant adjustments. Furthermore, they need to recognize, separate, and respect each of the initiatives that are in mutual conflict, while at the same time, managing their connections in order to achieve synergies (Smith et al., 2016).

\section{Discussion}

The main purpose of this study was to reconsider some of the commonly used notions and assumptions of board strategizing and develop a framework that illuminates the dynamics under which boards strategize in a digital era. We follow researchers arguing that it is essential to understand the preconditions under which boards are involved in strategy (Garg \& Eisenhardt, 2016; Hendry \& Kiel, 2004; Hendry et al., 2010; Rindova, 1999). By building on the work of McNulty and Pettigrew (1999), our study is one of the first providing a picture of how digitalization may substantially influence board strategizing. We explore board strategizing by contrasting the impact of digitalization through a corporate governance and strategic management perspective. This enables new significant contributions that emerge at the intersection of board strategizing and dynamic capabilities research.

We connect literature on board strategizing with literature on digitalization, a topic which is rarely considered in research on boards in general and board strategizing in particular (Tihanyi et al., 2014). We present a framework that depicts how digitalization will play a central role in changing board realities. As such, we enrich the discussion that boards in the future might look and operate considerably different from what we know today (Bankewitz et al., 2016; Valentine, 2014). As management scholars, we consider this of great importance as informing practitioners and policy makers about these predictions allow them to think ahead and anticipating future scenarios. This research could be further extended by giving specific attention to whether boards adjusting to the strategizing described in this article has positive performance contributions. Thus, conducting similar research to Brynjolfsson and McElheran (2016) but with boards as unit of analysis, may be particularly fruitful.

To theory our contribution is to the dynamic capabilities perspective. In general, hardly any research applying the dynamic capabilities perspective (Eisenhardt \& Martin, 2000; Teece et al., 1997) nor ambidexterity (O'Reilly \& Tushman, 2008) has been conducted in a board setting. We enrich the dynamic capabilities perspective and show that sensing, seizing, and reconfiguring capabilities are important capabilities that boards may apply in digital and fast changing environments as they strategize (Teece, 2007). In part, we argue that the dynamic capabilities a board 
possesses can allow them to efficiently outline relevant strategic actions and priorities, thus enhancing the dynamic capabilities of their organizations (Kor \& Mesko, 2013). In this regard, we add to the research examining how boards can be important resources and show that the dynamic capabilities of the board may be critical in contributing to organizations ability to create strategic change (Helfat \& Martin, 2014). Furthermore, we expand on the discussion that executives and particularly boards need to promote and engage in ambidextrous behavior and thus simultaneously exploit and explore opportunities (O'Reilly \& Tushman, 2008; Smith et al., 2016). In this regard, we underline that ambidextrous behavior by boards may be most critical in explaining successful board strategizing, especially for firms needing to make critical transitions and achieve strategic change as of digitalization. Future studies could build on these insights to empirically study boards use of dynamic capabilities and ambidextrous behavior in strategizing and their impact on strategic change, thus bringing a dynamic extension to the work of researchers who have looked at more static board resources and their impact on strategic change (Golden \& Zajac, 2001; Haynes \& Hillman, 2010).

The discussions of this conceptual paper offer several practical implications. These practical implications are particularly relevant as digitalization will have greater impact on organizations and the way they strategize in the future (Constantiou \& Kallinikos, 2015; McAfee \& Brynjolfsson, 2012). As such, our research provides a number of timely board practices that have the potential to improve board strategizing. First, boards need to form new internal (e.g. brainstorming sessions and dyadic relationships) and external forums (e.g. virtual networks) in order to improve their ability to sense opportunities and shape new decisions. Through such activities, boards can be better informed about internal and external developments and thus sense opportunities and shape decisions that allow their firms to respond to environmental changes and implications of digitalization in due time. Second, it is important to acknowledge that the practice of using data-driven decisions can improve board decision taking. That is, boards need to make sure that real time data is used to enhance their decision making, as data-driven decisions are becoming central to business success. Finally, boards have great overall impact on the way organizations strategize. As such boards can serve as figureheads for using dynamic capabilities as they strategize. Such a behavior could sustainably influence the dynamic capabilities of the whole organization, and the ability of the organization to form timely and relevant strategic actions.

We acknowledge that the study has some limitations which could be points of departure for future research. First, the study explores boards from a general perspective. Upcoming studies may be advised to empirically examine our framework in more specific contexts where it might be more applicable. Of interest could be firms fazing high environmental dynamism and technical innovation as such contexts may require more dynamic capabilities (Barrales-Molina, Bustinza, \& Gutiérrez-Gutiérrez, 2013; Drnevich \& Kriauciunas, 2011). Additionally, the impact of digitalization on boards might be more significant in such contexts. Second, given the rapid rate of change caused by digitalization, it is a challenge to think ahead and predict future scenarios. Research could therefore build on scenario planning methodology which have successfully been applied to study and predict future developments when uncertainty and complexity are high (Amer, Daim, \& Jetter, 2013; van Notten, Rotmans, van Asselt, \& Rothman, 2003; Varum \& Melo, 2010). Scenario planning could be beneficial as it is prone to facilitate the purpose of overcoming blind spots in corporate governance and stretch peoples thinking when exploring how digitalization will impact boards in the uncertain and complex future.

\section{Conclusion}

Few insights exist on how boards stay competitive in environments of increasing digitalization. This gap in literature has brought our attention in this paper. We show that the complexities and dynamics firms are facing, as of increasing digitalization, are specifically challenging some of the commonly used notions and assumptions of board strategizing. Using the dynamic capabilities perspective, we conceptualize a new model for board strategizing considering increasing digitalization. Our model is particularly relevant in the context of exploring new elements of board strategizing, and may help board members to recognize, reconsider, and reflect on aspects that make boards fit for strategizing in the future.

\section{References}

Adner, R., \& Helfat, C. E. (2003). Corporate effects and dynamic managerial capabilities. Strategic Management Journal, 24, 1011-1025. https://doi.org/10.1002/smj.331

Altman, E. J., \& Tushman, M. L. (2017). Platforms, open/user innovation, and ecosystems: A strategic leadership perspective. Harvard Business School Organizational Behavior Unit Working Paper No. 17-076. 
Amer, M., Daim, T. U., \& Jetter, A. (2013). A review of scenario planning. Futures, 46, 23-40. https://doi.org/10.1016/j.futures.2012.10.003

Augier, M., \& Teece, D. J. (2008). Strategy as evolution with design: The foundations of dynamic capabilities and the role of managers in the economic system. Organization Studies, 29(8-9), 1187-1208. https://doi.org/10.1177/0170840608094776

Bailey, B. C., \& Peck, S. I. (2013). Boardroom strategic decision-making style: Understanding the antecedents. Corporate Governance: An International Review, 21(2), 131-146. https://doi.org/10.1111/corg.12008

Bankewitz, M., Åberg, C., \& Teuchert, C. (2016). Digitalization and boards of directors: A new era of corporate governance? Business and Management Research, 5(2), 58-69. https://doi.org/10.5430/bmr.v5n2p58

Barrales-Molina, V., Bustinza, Ó. F., \& Gutiérrez-Gutiérrez, L. J. (2013). Explaining the causes and effects of dynamic capabilities generation: A multiple-indicator multiple-cause modelling approach. British Journal of Management, 24(4), 571-591. https://doi.org/10.1111/j.1467-8551.2012.00829.x

Beck, J. B., \& Wiersema, M. F. (2013). Executive decision making: Linking dynamic managerial capabilities to the resource portfolio and strategic outcomes. Journal of Leadership \& Organizational Studies, 20(4), 408-419. https://doi.org/10.1177/1548051812471722

Binns, A., Harreld, B. J., O'Reilly, C., \& Tushman, M. L. (2014). The art of strategic renewal. Harvard Business Review, 55(20-23).

Boivie, S., K. Bednar, M., Aguilera, R. V., \& Andrus, J. L. (2016). Are boards designed to fail? The implausibility of effective board monitoring. The Academy of Management Annals, 1-89. https://doi.org/10.1080/19416520.2016.1120957

Brynjolfsson, E., \& McElheran, K. (2016). The rapid adoption of data-driven decision-making. American Economic Review, 106(5), 133-139. https://doi.org/10.1257/aer.p20161016

Collin, J., Hiekkanen, K., Korhonen, J., Halén, M., Itälä, T., \& Helenius, M. (2015). IT leadership in transition - The impact of digitalization on Finnish organizations. Aalto University publication series.

Constantiou, I. D., \& Kallinikos, J. (2015). New games, new rules: big data and the changing context of strategy. Journal of Information Technology, 30(1), 44-57. https://doi.org/10.1057/jit.2014.17

Croon Fors, A. (2013). The Ontology of the Subject in Digitalization, Handbook of Research on Technoself: Identity in a Technological Society, 45-63.

Davenport, T. H., \& Patil, D. J. (2012). Data scientist: The sexiest job of the 21 st century. Harvard Business Review(October).

Davis, J. P., Eisenhardt, K. M., \& Bringham, C. B. (2009). Optimal structure, market dynamism, and the strategy of simple rules. Administrative Science Quarterly, 54(3), 413-452.

Downes, L., \& Nunes, P. (2013). Big-bang disruption. Harvard Business Review(March).

Dreischmeier, R., Close, K., \& Trichet, P. (2015). The digital imperative. BCG Perspectives

Drnevich, P., \& Croson, D. (2013). Information technology and business-level strategy: Toward an integrated theoretical perspective. MIS Quarterly, 37(2), 483-509.

Drnevich, P. L., \& Kriauciunas, A. P. (2011). Clarifying the conditions and limits of the contributions of ordinary and dynamic capabilities to relative firm performance. Strategic Management Journal, 32(3), 254-279. https://doi.org/10.1002/smj.882

Eisenhardt, K. M., \& Martin, J. A. (2000). Dynamic capabilities: What are they? Strategic Management Journal, 21, 1105-1121. https://doi.org/10.1002/1097-0266(200010/11)21:10/11<1105::AID-SMJ133>3.0.CO;2-E

Fama, E. F., \& Jensen, M. C. (1983). Separation of Ownership and Control. Journal of Law and Economics, 26(June), 301-325. https://doi.org/10.2139/ssrn.94034

Finkelstein, S., Hambrick, D. C., \& Cannella, A. A. (2009). Strategic leadership: theory and research on executives, top management teams, and boards. USA: Oxford University Press. https://doi.org/10.1093/acprof:oso/9780195162073.001.0001 
Forbes, D. P., \& Milliken, F. J. (1999). Cognition and corporate governance; Understanding boards of directors as strategic decision-making groups. Academy of Management Review, 24(3), 489-505. https://doi.org/10.5465/AMR.1999.2202133

Garg, S., \& Eisenhardt, K. M. (2016). Unpacking the CEO-board relationship: How strategy-making happens in entrepreneurial firms. Academy of Management Journal, Forthcoming. https://doi.org/10.5465/amj.2014.0599

Gibson, C. B., \& Birkinshaw, J. (2004). The antecedents, consequences, and mediating role of organizational ambidexterity. Academy of Management Journal, 47(2), 209-226. https://doi.org/10.2307/20159573

Golden, B. R., \& Zajac, E. J. (2001). When will boards influence strategy? inclination $\times$ power $=$ strategic change. Strategic Management Journal, 22(12), 1087-1111. https://doi.org/10.1002/smj.202

Haynes, K. T., \& Hillman, A. J. (2010). The effect of board capital and CEO power on strategic change. Strategic Management Journal, 31, 1145-1163. https://doi.org/10.1002/smj.859

Helfat, C. E., \& Martin, J. A. (2014). Dynamic managerial capabilities: Review and assessment of managerial impact on strategic change. Journal of Management, 41(5), 1281-1312. https://doi.org/10.1177/0149206314561301

Helfat, C. E., \& Peteraf, M. A. (2015). Managerial cognitive capabilities and the microfoundations of dynamic capabilities. Strategic Management Journal, 36(6), 831-850. https://doi.org/10.1002/smj.2247

Hendry, K., \& Kiel, G. (2004). The role of the board in firm strategy: Integrating agency and organisational control perspectives. Corporate Governance: An International Review, 12(4), 500-520. https://doi.org/10.1111/j.1467-8683.2004.00390.x

Hendry, K. P., Kiel, G. C., \& Nicholson, G. (2010). How boards strategise: A strategy as practice view. Long Range Planning, 43(1), 33-56. https://doi.org/10.1016/j.lrp.2009.09.005

Hirt, M., \& Willmott, P. (2014). Strategic principles for competing in the digital age. McKinsey Quarterly. Retrieved from

http://www.mckinsey.com/business-functions/strategy-and-corporate-finance/our-insights/strategic-principles-f or-competing-in-the-digital-age

Jensen, M., \& Zajac, E. J. (2004). Corporate elites and corporate strategy: how demographic preferences and structural position shape the scope of the firm. Strategic Management Journal, 25(6), 507-524. https://doi.org/10.1002/smj.393

Ko, D., \& Fink, D. (2010). Information technology governance: an evaluation of the theory-practice gap. Corporate Governance: The International Journal of Business in Society, 10(5), 662-674. https://doi.org/10.1108/14720701011085616

Kor, Y. Y., \& Mesko, A. (2013). Dynamic managerial capabilities: Configuration and orchestration of top executives' capabilities and the firm's dominant logic. Strategic Management Journal, 34(2), 233-244. https://doi.org/10.1002/smj.2000

Kriz, A., Voola, R., \& Yuksel, U. (2014). The dynamic capability of ambidexterity in hypercompetition: qualitative insights. Journal of Strategic Marketing, 22(4), 287-299. https://doi.org/10.1080/0965254x.2013.876075

McAfee, A., \& Brynjolfsson, E. (2012). Big data: The management revolution. Harvard Business Review, 90(10), 61-67.

McNulty, T., \& Pettigrew, A. (1999). Strategists on the board. Organization Studies, 20(1), 47-74. https://doi.org/10.1177/0170840699201003

Newell, S., \& Marabelli, M. (2014). The crowd and sensors era: Opportunities and challenges for individuals, organizations, society, and researchers. ICIS.

Newell, S., \& Marabelli, M. (2015). Strategic opportunities (and challenges) of algorithmic decision-making: A call for action on the long-term societal effects of 'datification'. The Journal of Strategic Information Systems, 24(1), 3-14. https://doi.org/10.1016/j.jsis.2015.02.001

O'Reilly, C., \& Tushman, M. L. (2008). Ambidexterity as a dynamic capability: Resolving the innovator's dilemma. Research in Organizational Behavior, 28, 185-206. https://doi.org/10.1016/j.riob.2008.06.002

O'Reilly, C., \& Tushman, M. L. (2013). Organizational ambidexterity: Past, present, and future. The Academy of Management Perspectives, 27(4), 324-338. https://doi.org/10.5465/amp.2013.0025 
Orlikowski, W. J., \& Scott, S. V. (2014). What happens when evaluation goes online? Exploring apparatuses of valuation in the travel sector. Organization Science, 25(3), 868-891. https://doi.org/10.1287/orsc.2013.0877

Pugliese, A., Bezemer, P.-J., Zattoni, A., Huse, M., Van den Bosch, F. A. J., \& Volberda, H. W. (2009). Boards of directors' contribution to strategy: A literature review and research agenda. Corporate Governance: An International Review, 17(3), 292-306. https://doi.org/10.1111/j.1467-8683.2009.00740.x

Pye, A. (2002). Corporate directing: Governing, strategising and leading in action. Corporate Governance: An International Review, 10(3), 153-162. https://doi.org/10.1111/1467-8683.00280

Rindova, V. (1999). What corporate boards have to do with strategy: A cognitive perspective. Journal of Management Studies, 36(7). https://doi.org/10.1111/1467-6486.00165

Smith, W. K., Lewis, M. W., \& Tushman, M. L. (2016). "Both/and" leadership; Don’t worry so much about being consistent. Harvard Business Review(May 2016).

Spring, T. (2015). Cisco's Chambers: 'Disrupt yourself, or be disrupted', CRN. Retrieved from http://www.crn.com/news/networking/300075285/ciscos-chambers-disrupt-yourself-or-be-disrupted.htm

Stiles, P. (2001). The impact of the board on strategy: An empirical examination. Journal of Management Studies, 38(5), 627-650. https://doi.org/10.1111/1467-6486.00252

Sundaramurthy, C., \& Lewis, M. W. (2003). Control and collaboration: Paradoxes of governance. Academy of Management Review, 28(3), 397-415. https://doi.org/10.5465/AMR.2003.10196737

Taylor, A., \& Helfat, C. E. (2009). Organizational Linkages for Surviving Technological Change: Complementary Assets, Middle Management, and Ambidexterity. Organization Science, 20(4), 718-739. https://doi.org/10.1287/orsc.1090.0429

Teece, D. J. (2007). Explicating dynamic capabilities: the nature and microfoundations of (sustainable) enterprise performance. Strategic Management Journal, 28(13), 1319-1350. https://doi.org/10.1002/smj.640

Teece, D. J., Pisano, G., \& Shuen, A. (1997). Dynamic capabilities and strategic management. Strategic Management Journal, 18(7), 509-533. https://doi.org/10.1002/(SICI)1097-0266(199708)18:7<509::AID-SMJ882>3.0.CO;2-Z

Tihanyi, L., Graffin, S., \& George, G. (2014). Rethinking governance in management research. Academy of Management Journal, 57(6), 1535-1543. https://doi.org/10.5465/amj.2014.4006

Tushman, M. L., \& O'Reilly, C. (1996). Ambidextrous organizations: Managing evolutionary and revolutionary change. California Management Review, 38(4), 8-30. https://doi.org/10.2307/41165852

Valentine, E. (2014). Are boards flying blind when it comes to enterprise technology governance? Edpacs, 49(2), 1-5. https://doi.org/10.1080/07366981.2014.881163

van den Driest, F., Sthanunathan, S., \& Weed, K. (2016). Building an Insights Engine. Harvard Business Review(September).

van Notten, P. W. F., Rotmans, J., van Asselt, M. B. A., \& Rothman, D. S. (2003). An updated scenario typology. Futures, 35(5), 423-443. https://doi.org/10.1016/s0016-3287(02)00090-3

Varum, C. A., \& Melo, C. (2010). Directions in scenario planning literature - A review of the past decades. Futures, 42(4), 355-369. https://doi.org/10.1016/j.futures.2009.11.021

Westphal, J. D., \& Fredrickson, J. W. (2001). Who directs strategic change? Director experience, the selection of new CEOs, and change in corporate strategy. Strategic Management Journal, 22(12), 1113-1137. https://doi.org/10.1002/smj.205

Yayla, A. A. (2014). The effect of board of directors' IT awareness on CIO compensation and firm performance. Decision Science, 45(3), 401-436. https://doi.org/10.1111/deci.12077

Zahra, S., Sapienza, H. J., \& Davidsson, P. (2006). Entrepreneurship and dynamic capabilities: A review, model and research agenda. Journal of Management Studies, 43(4), 917-955. https://doi.org/10.1111/j.1467-6486.2006.00616.x

Zattoni, A., Gnan, L., \& Huse, M. (2015). Does family involvement influence firm performance? Exploring the mediating effects of board processes and tasks. Journal of Management, 41(4), 1214-1243. https://doi.org/10.1177/0149206312463936 